\title{
OSOBOWOŚĆ NIEDOJRZAŁA JAKO PODSTAWA ORZECZENIA NIEWAŻNOŚCI MAŁŻEŃSTWA W ŚWIETLE WYROKÓW ROTY RZYMSKIEJ I TRYBUNAŁÓW KOŚCIELNYCH
}

Treść: Wprowadzenie. - 1. Kanoniczne określenia osobowości dojrzałej. - 2. Kryteria osobowości niedojrzałej. - 3. Osobowość niedojrzała a niezdolność do podjęcia i wypełnienia istotnych obowiązków małżeńskich. - Zakończenie.

\section{Wprowadzenie}

Z materiałów dowodowych procesów kościelnych, prowadzonych zwłaszcza z kan. 1095 n. 3 KPK z 1983 r., wynika, że osobowość niedojrzała posiada swoje źródło w rodzinie patologicznej albo w wadliwym wychowaniu, bądź jest dziedziczona genetycznie. $Z$ tego też względu potomstwo wychowujące się w takich rodzinach może okazać się niezdolne do podjęcia istotnych obowiązków małżeńskich. W wielu wyrokach trybunałów kościelnych stwierdzono nieważność małżeństwa z powodu występowania właśnie osobowości niedojrzałej. Zagadnienie dotyczące osobowości niedojrzałej należy do trudnych tematów w psychologii i z tego względu stanowi powód wielu dyskusji. Niemniej jednak warto zaznaczyć, że termin „osobowość” w potocznym zastosowaniu posiada różne znaczenie zarówno psychologiczne, jak i prawne. Na zagadnienie to zwracają uwagę niektórzy autorzy wskazując na kan. 1095 KPK z 1983 r., przy którego stosowaniu analizuje się osobowość człowieka w aspekcie psychologicznym, gdyż poziom jej ukształtowania, a zwłaszcza jej brak, posiada dość poważne 
konsekwencje prawne ${ }^{1}$. Zatem osobowość to zbiór względnie stałych dla danej jednostki właściwości (cech) psychicznych warunkujących stałość jej zachowania i postaw ${ }^{2}$.

W związku z tym warto przypomnieć dwie wypowiedzi Jana Pawła II na temat „dojrzałości psychicznej” oraz „,dojrzałości kanonicznej”. W pierwszej z dnia 25 stycznia 1988 r. Ojciec św. podkreślił, iż: „dojrzałość psychologiczną”, która stanowi punkt dojścia w rozwoju człowieka, nie można łączyć z „,dojrzałością kanoniczną”, która z kolei jest minimalnym punktem wyjścia dla ważności małżeństwa ${ }^{3}$.

${ }^{1}$ R. SzTyChmiler, Znaczenie osobowości kandydata do matzeństwa $w$ świetle obowiazujacego prawa kanonicznego, Prawo Kanoniczne 40 (1997) nr 1-2, s. 201.

2 Nowa encyklopedia powszechna PWN, t. 4, Warszawa 1996, s. 697.

${ }^{3}$ L'Osservatore Romano, wydanie polskie 9 (1988) nr 1, s. 6 i 23. Ojciec św. Jan Paweł II wyjaśnił, że pojęcie ,dojrzałości psychologicznej” wskazywane przez psychologów i psychiatrów powinno zostać zweryfikowane w myśl koncepcji antropologii chrześcijańskiej. Ponadto Jan Paweł II zaznaczył, iż współczesna psychologia i psychiatria w konstruowaniu definicji psychicznej normalności bierze pod uwagę tylko doczesny i naturalny wymiar osoby, natomiast pomija całościową wizję osoby oraz jej powołanie do wieczności, a także do transcendentalnych wartości religijnych i moralnych. Jednocześnie Jan Paweł II podkreślił, że dla psychologa i psychiatry każda forma patologii psychicznych może wykraczać poza pojęcie normalności. Ponadto wyjaśnił, że dla kanonisty, który opiera się na chrześcijańskiej antropologii człowieka, koncepcja normalności obejmuje lekkie formy trudności psychicznych. Wobec tego brak integralnej wizji istoty ludzkiej doprowadza do tego, że w teorii normalny stan psychiczny staje się mitem, z kolei w praktyce pozwala uznać większość ludzi zawierających małżeństwo za niezdolnych do ważnego wyrażania zgody małżeńskiej; W. KRUPA, Zasady opracowywania opinii biegłego psychologa w sprawach o nieważność matżeństwa, w: Ius Matrimoniale, t. 1 (6-7), Warszawa 1996, s. 138-139. Autor wyjaśnił, że „dojrzałość psychiczna” rozumiana równoznacznie z dojrzałością osobowościową - emocjonalną, a więc zdolnością do przejawiania reakcji emocjonalnych adekwatnych do normy dla danego wieku, zrównoważeniem emocjonalnym i wolitywnym, zdolnością do przeżywania i przejawiania uczuć wyższych oraz społeczną, czyli osiagnięciem określonego poziomu rozwoju społecznego, na którym człowiek przejawia gotowość do opanowania i pełnienia ról przypisanych przez społeczeństwo - pozostaje w ścisłym związku z otaczającą rzeczywistością. Autor zaznaczył także, że dla psychologa zajmującego się opiniowaniem w sprawach o nieważność małżeństwa w kwestii dotyczącej struktury osobowości przydatne są następujące przejawy zaburzeń: niedojrzałość emocjonalna i społeczna, dysharmonia osobowości, niespójność w ocenach i sądach, zaburzenia sfery wolicjonalnej, cechy degradacji osobowościowej 
W drugiej zaś wypowiedzi Ojciec św. powołał się na dokumenty Vaticanum II i przypomniał naukę Kościoła katolickiego, zgodnie z którą człowiek stanowi istotę stworzoną na obraz Boży, która jest zdolna do poznania i miłowania swego Stwórcy ${ }^{4}$. Poza tym należy jeszcze przypomnieć przemówienie Jana Pawła II do Roty Rzymskiej z dnia 27 stycznia 1997 r., w którym wskazał na walor prawny i wymiar osobowy małżeństwa. W tej wypowiedzi Ojciec św. zwrócił uwagę na to, że normy kanoniczne stanowią tylko wyraz prawny, pod którym kryje się rzeczywistość antropologiczna i teologiczna ${ }^{5}$. Można zatem powiedzieć, że w pewnym sensie orzecznictwo trybunałów kościelnych wyprzedza naukę prawa kanonicznego w kwestii orzekania o nieważności małżeństwa, czego przykładem jest rozumienie terminu „osobowości niedojrzałej”, które występuje w wyrokach trybunałów kościelnych i jest określane przez powoływanych biegłych sądowych psychologów albo psychiatrów, jako jeden z typów zaburzenia osobowości.

\section{Kanoniczne określenia osobowości dojrzałej}

Badania naukowe i rozwijająca się wiedza medyczna i psychologiczna doprowadziły do rozbudowania i zmodyfikowania tytułów

wskutek uzależnienia od alkoholu, charakteropatia pourazowa, psychiczne uwarunkowania istotnych zaburzeń w sferze aktywności seksualnej.

${ }^{4}$ L'Osservatore Romano, wydanie polskie 8 (1987) nr 2, s. 32. Ojciec św. Jan Paweł II przypomniał koncepcję chrześcijańską, według której powołaniem człowieka jest przylgnięcie do Boga, jako ostatecznego celu, w którym znajduje on swoje spełnienie, chociaż w urzeczywistnianiu tego powołania napotyka na przeszkody, które wynikają z oporu, jaki wywołuje w nim stan pożądliwości. Jan Paweł II przypomniał także nauczanie Soboru Trydenckiego, zgodnie z którym urzeczywistnianie sensu związku małżeńskiego następuje poprzez obdarowywanie się na drodze nieustannego wysiłku, w tym również wyrzeczenia i poświęceń. Jednocześnie Ojciec św. dodał, że wzajemna miłość małżonków powinna kształtować się na wzór samego Chrystusa.

${ }^{5}$ L'Osservatore Romano, wydanie polskie 7 (1997) nr 2, s. 46. Ojciec św. Jan Paweł II podkreślił, że dostrzega trudność sędziów orzekających o nieważność małżeństwa, zwłaszcza jeżeli dotyczy to tytułu psychicznej niezdolności do podjęcia istotnych obowiązków małżeńskich. Jan Paweł II wyjaśnił również, że jego pragnieniem jest, żeby za pomocą nauk humanistycznych można było określić chociażby minimum, poniżej którego nie można mówić o zdolności do zawarcia prawdziwego małżeństwa sakramentalnego. 
nieważności małżeństwa w Kodeksie Prawa Kanonicznego z 1983 r. W związku z tym większą uwagę zwraca się na sam akt wyrażania zgody małżeńskiej, która powinna być aktem w pełni osobowym i wolnym od jakichkolwiek ograniczeń. Poza tym wykorzystując wiedzę pochodząca z nauk medycznych i psychologicznych można wskazać czynniki, które mogą w pewnym stopniu ograniczać lub uniemożliwiać zdolność do wyrażenia zgody małżeńskiej ${ }^{6}$. Zgodnie z opinią niektórych autorów dojrzałość psychologiczna połączona jest z autonomią wewnętrzną, określonym systemem wartości oraz z nastawieniem prospołecznym w relacjach interpersonalnych ${ }^{7}$.

Literatura przedmiotu wymienia następujące cechy „osobowości dojrzałej”, czyli: „miłość pomimo, szacunek pomimo, tolerancja pomimo, akceptacja pomimo". Poza tym do cech „osobowości dojrzałej” zalicza się także trwałą hierarchię wartości i charakterystyczny stosunek do siebie, czyli zaakceptowanie siebie samego. Znawcy tematu podkreślają, że dojrzałość człowieka polega na osiagnięciu cech osób dorosłych ${ }^{9}$. Wobec tego można powiedzieć, że sam proces „dojrzało-

${ }^{6}$ S. Kosowicz, Zaburzenia psychiczne ograniczajace wykonanie zobowiazań powziętych $w$ akcie zgody matżénskiej, Prawo Kanoniczne 29 (1986) nr 1-3, s. 217-226.

7 W. Prężyna, Problem psychologicznych kryteriów niezdolności do podjęcia i wypetnienia zobowiqzań matżeńskich, Kościół i Prawo, t. 4, Lublin 1989, s. 103-114. Autor wyjaśnia, że „dojrzałość psychologiczna” stanowi powiedzmy punkt rozwoju, w którym jednostka jest świadoma i wolna w działaniu i dostosowaniu się do pewnych swych ideałów. Poza tym zaznaczył, że dojrzałość ta łączy się również ze zdolnością do zmierzenia się z wewnętrznymi i zewnętrznymi trudnościami. Jednocześnie Autor podkreśla, że „dojrzała osobowość” charakteryzuje się umiejętnością komunikowania z drugim człowiekiem, a więc umiejętnością powiedzmy nazywania i wyrażania własnych uczuć, jak również zdolnością akceptowania drugiego człowieka bez stawiania mu warunków i wyzwoleniem się z dominacji mechanizmów obronnych, które są podświadomym i zafałszowanym widzeniem i interpretacji rzeczywistości, idące w stronę życzeń lub obaw, a służące właściwie zachowaniu dobrego samopoczucia albo mniemania o sobie. Ponadto Autor zaznaczył, że „osobowość dojrzałą” cechuje niestosowanie przemocy.

${ }^{8}$ E. SuJAK, Życie jako zadanie, Warszawa 1982, s. 167.

9 M. Masiak, Zaburzenia osobowości w ujęciu klinicznym, w: Wykłady z psychologii w Katolickim Uniwersytecie Lubelskim w roku akademickim 1986/87, Lublin 1989, s. 268. 
ści" jest zorientowany na nieosiagalną w ziemskim życiu pełnię ${ }^{10}$. Tak więc „osobowość dojrzała” stanowi pewien ideał, a samo kształtowanie się „osobowości dojrzałej” jest ciagłym i trwającym przez całe życie procesem, dzięki któremu człowiek przyjmuje odpowiedzialność za swoje własne życie i rozwija się w niepowtarzalny sposób ${ }^{11}$.

Zgodnie z opinią niektórych autorów dla sędziego kościelnego istotna jest „dojrzałość kanoniczna”, która stanowi punkt wyjścia oceny ważności lub nieważności małżeństwa ${ }^{12}$. Inni autorzy zaś podają trzy wymiary dojrzałości, które wzajemnie się dopełniają, ale należy je odrębnie traktować ${ }^{13}$. Stanowią one wewnętrzną autonomię, układ wartości funkcjonujący, jako autonomiczny system motywacyjny oraz nastawienie allocentryczne $\mathrm{w}$ postawach interpersonalny $\mathrm{ch}^{14}$. Jednocześnie należy zauważyć, że ocenę dojrzałości trzeba odnieść powiedzmy „do czegoś”, bowiem dojrzałość w jednym zakresie może iść $\mathrm{w}$ parze $\mathrm{z}$ niedojrzałością $\mathrm{w}$ innym zakresie. $\mathrm{Z}$ tego też względu w odniesieniu do małżeństwa nie można mówić o pełnej dojrzałości, czy też „pełnej dojrzałości małżeńskiej”, ale tylko o odpowiedniej dojrzałości, a więc „minimalnej”, czyli „dojrzałości kanonicznej”, która wymagana jest przez prawo do ważnego zawarcia małżeństwa ${ }^{15}$. Warto jeszcze zaznaczyć, że wielu psychiatrów wprowadziło podziały kliniczne, które szeregują ludzi zaburzonych na podgrupy, według których zaburzenia osobowości stanowią ciężkie zaburzenia struktury charakteru i sposobu zachowania się osoby, które z kolei obejmują kilka wymiarów osobowości ${ }^{16}$.

${ }^{10}$ Dec. z dnia 15 października 1992 r. c. Burke, Monitor Ecclesiasticus 118 (1993), S. 563.

${ }^{11}$ Z. CHLEwIŃsKi, Refleksje o dojrzałej osobowości, Lublin 1985, s. 318.

${ }^{12}$ M. Żurowski, Niezdolność do podjęcia obowiazków matżeńskich z przyczyn psychicznych, Prawo Kanoniczne 29 (1986) nr 3-4, s. 153-162.

${ }^{13}$ W. Prężyna, Problem psychologicznych kryteriów..., s. 104.

${ }^{14}$ Tamże.

${ }^{15}$ Por. Dec. z dnia 20 marca 1001 r. c. Colagiovanni; R. SoBAŃSKI, Wyrok Sadu Metropolitalnego w Katowicach (w trzeciej instancji) c. Sobański z dnia 12 grudnia 1996 r. w sprawie o nieważność matżeństwa z tytułu niezdolności do podjęcia obowiqzków matżeńskich (kan. 1095 n. 3), w: Ius Matrimoniale, t. 2 (8), Warszawa 1997, s. 229.

${ }^{16}$ Por. H. Clekley, The Mask of Sainty, Saint Louis 1976, s. 337-338; Międzyna- 
Warto jeszcze zwrócić uwagę na następujące kryteria diagnostyczne osobowości nieprawidłowej, czyli m.in.: trwałą niezdolność do związków uczuciowych z innymi ludźmi, bezosobowy stosunek do życia seksualnego (przedmiotowe traktowanie partnera), brak poczucia winy, wstydu i odpowiedzialności, jak również utrwalone i nieadekwatne zachowania antyspołeczne, autodestrukcyjny wzorzec życia, nierozróżnianie granicy między rzeczywistością a fikcją, prawdą a kłamstwem, brak lęku, częste szantażowanie samobójstwem oraz tendencja do samouszkodzeń ${ }^{17}$. Wskazane cechy osobowości niedojrzałej doprowadzają do tego, iż dla potrzeb prawa kanonicznego nie wystarczy mówić tylko o samym terminie niedojrzałości, jako kryterium oceny niezdolności do ważnego zawarcia małżeństwa. Istnieje potrzeba określenia punktu krytycznego tej właśnie niezdolności, po-

rodowa Statystyczna Klasyfikacja Chorób i Problemów Zdrowotnych. Rewizja dziesiata. Klasyfikacja zaburzeń psychicznych i zaburzeń zachowania w ICD - 10. Opisy kliniczne i wskazówki diagnostyczne, Kraków - Warszawa 1997, s. 170. Międzynarodowa klasyfikacja wymienia następujące postacie zaburzeń osobowości, czyli: 1. Osobowość paranoiczna, która zawiera w sobie zaburzenia osobowości: osobowość ekspansywno-paranoiczna, osobowość fantastyczną, osobowość pieniaczą, osobowość paranoidalną, osobowość sensytywno-paranoiczna. 2. Osobowość schizoidalną. 3. Osobowość dyssocjalną, która zawiera w sobie osobowości: osobowość amoralna, osobowość antysocjalną, osobowość asocjalną, osobowość psychopatyczna, osobowość socjopatyczną. 4. Osobowość chwiejną emocjonalnie, która zawiera w sobie zaburzenia osobowości: osobowość agresywna, osobowość „,borderline”, osobowość eksplozywną. 5. Osobowość histrioniczną, która zawiera w sobie zaburzenia osobowości: osobowość histeryczna, osobowość psychoinfantylną. 6. Osobowość anankastyczną, która zawiera w sobie osobowości: osobowość kompulsywną, osobowość obsesyjną, osobowość kompulsywno-obsesyjną. 7. Osobowość lękliwą (unikająca). 8. Osobowość zależną, która zawiera w sobie osobowości: osobowość asteniczną, osobowość nieadekwatną, osobowość bierną, osobowość samoponiżającą się. Wymieniono równie inne zaburzenia osobowości, m. in. osobowość ekscentryczną, osobowość uległa, osobowość niedojrzałą, osobowość narcystyczną, osobowość bierno-agresywną oraz osobowość psychoneurotyczną. Poza tym mogą istnieć jeszcze osobowości mieszane.

${ }^{17}$ Por. A. JAKUBIK, Zaburzenia osobowości, Warszawa 1997, s. 58; J. JAROSZYŃSKI, Zespoty zaburzeń psychicznych, w: Psychiatria, (red.), A. Bilikiewicz, S. Strzyżewski, Warszawa 1992, s. 39; A. JAKUBIK, Zaburzona osobowość, w: Psychiatria, t. 1, Warszawa 1987 , s. 237-238. 
niżej której niedojrzałość doprowadza do tego, iż jednostka jest już niezdolna do ważnego zawarcia małżeństwa, a więc podjęcia się zobowiązań małżeńskich i przy tym realizacji tej umowy, czyli wypełnienia tych zobowiązań. I dopiero w taki sposób rozumianą niedojrzałość kryterialną można uznać za przeszkodę do ważnego zawarcia umowy małżeńskiej. Jednocześnie nasuwa się wątpliwość, czyli: kto i w jaki sposób może określić poziom niedojrzałości kryterialnej, jako przeszkody do ważnego zawarcia małżeństwa? Biorąc pod uwagę opinie niektórych autorów można powiedzieć, że tylko biegły sądowy, czyli psycholog lub psychiatra, może pomóc w określeniu niedojrzałości kryterialnej. Niemniej jednak można dokonać tego tylko w dwóch etapach. Pierwszy etap zawiera ocenę danej jednostki diagnostycznej, jako postaci psychologicznej niedojrzałości, oczywiście pod kątem stopnia zakłócenia przez nią określonych procesów i funkcji psychicznych człowieka. Ocena ta zostaje przeprowadzona w dwóch poziomach, a mianowicie: teoretycznym i praktycznym. W pierwszym poziomie ocenia się modelowo niedojrzałość kryterialna, natomiast w drugim poziomie następuje ocena modelu tej niedojrzałości odnoszącego się do konkretnego przypadku. Z kolei w drugim etapie ocenia się, na ile określona postać niedojrzałości znosi, z uwagi na wywołane przez nią zakłócenia procesów psychicznych, istotne warunki zawarcia ważnej umowy małżeńskiej ${ }^{18}$.

\footnotetext{
${ }^{18}$ Por. A. GolęBIowsKa, Rozmowa psychologiczna i testy psychologiczne jako metody tworzenia opinii biegłego sqdowego w sprawach o nieważność matżeństwa, Seminare, t. 31 (2012), s. 49-68; W. PrĘżYna, Problem psychologicznych kryteriów..., s. 109. W niektórych opracowaniach można znaleźć opinie, według których dojrzałość psychiczna rozumiana jest równoznacznie z dojrzałością osobowościową - emocjonalną, czyli zdolnością do przejawiania reakcji emocjonalnych właściwych do normy dla danego wieku, zrównoważeniem emocjonalnym i wolitywnym, zdolnością do przeżywania i przejawiania uczuć wyższych; społeczną, a mianowicie osiągnięciem określonego poziomu rozwoju społecznego, na którym człowiek przejawia gotowość do opanowania i pełnienia ról przypisanych przez społeczeństwo, pozostającą w ścisłym związku z otaczającą rzeczywistością; W. KRUPA, Zasady opracowywania opinii..., s. 138 .
} 


\section{Kryteria osobowości niedojrzałej}

Nie ulega wątpliwości, że osobowość niedojrzała rzutuje na trwałość małżeństwa, co posiada swoje odbicie w wyrokach Roty Rzymskiej, gdzie na przestrzeni kilkunastu lat wydano orzeczenia, w których przyczyną rozpadu małżeństwa była osobowość niedojrzała ${ }^{19}$. Analizując przedstawioną argumentacją zawartą w orzeczeniach rotalnych, jak i trybunałów kościelnych można zauważyć wątpliwości co do jednoznacznej kwalifikacji psychologicznej oceny stopnia zdolności lub

${ }^{19}$ Por. M. P. Hilbert, Classificazione delle patologie psiche di tipo paranoide: analisi strutturale e giurisprudenza rotale di merito, Periodica 86 (1997), s. 138. Autor wymienia wyroki, które dotyczą osobowości niedojrzałej, czyli: dec. z dnia 3 lipca 1980 r. c. Parisella; dec. $z$ dnia 27 czerwca 1981 r. c. Ewers; dec. z dnia 12 lutego 1982 r. c. Pinto; dec. z dnia 19 lutego 1982 r. c. Pompedda; dec. z dnia 27 maja 1983 r. c. Pinto; dec. z dnia 9 lipca 1983 r. c Colagiovanni; dec. z dnia 11 października 1983r. c. Rerraro; dec. z dnia 5 marca 1985 r. c. Fiore; dec. z dnia 30 marca 1985 r. c. Di Felice; dec. z dnia 30 maja 1987 r. c. Fiore; dec. z dnia 6 czerwca 1987 r. c. Neuhaus; dec. $z$ dnia 27 stycznia 1989 r. c. Civilli; dec. z dnia 23 lutego 1990 r. c. Bruno; dec. z dnia 6 czerwca 1990 r. c. Jarawan; dec.. z dnia 24 października 1990 r. c. Doran. Jednocześnie należy wymienić jeszcze inne orzeczenia Roty Rzymskiej, gdzie rozpatrywano niezdolność konsensualną wywodzącą się z przyczyn natury psychicznej, a mianowicie: dec. z dnia 6 czerwca 1990 r. c. Palestro, Il Diritto Ecclesiastico 101 (1990), s. 218- 230; dec. $z$ dnia 8 marca 1975 r. c. Di Felice, Monitor Ecclesiasticus 113 (1988), s. 204-229; dec. z dnia 13 listopada 1979 r. c. Road, Monitor Ecclesiasticus 105 (1980), s. 30-33; dec. $z$ dnia 4 maja 1992 r. c. Pompedda, RRD 84 (1992), s. 224-225; dec. z dnia 1 lipca 1988 r. c. Doran, Ius Ecclesiae 2 (1990), s. 163-175; dec. z dnia 21 marca 1991 r. c. Doran, Monitor Ecclesiasticus 116 (1991), s. 544-574; dec. z dnia 18 grudnia 1991 r. c. Palestro, Monitor Ecclesiasticus 117 (1992), s. 186-200; dec. z dnia 31 stycznia 1976 r. c. Lefebvre, Ephemerides Iuris Canonici 32 (1976), s. 287-299; dec. z dnia 18 maja 1978 r. c. Parisella, Il Diritto Ecclesiastico 104 (1979), s. 10-37; dec. z dnia 17 lipca 1991 r. c. Bruno, Monitor Ecclesiasticus 117 (1992), s. 173-192; dec. z dnia 12 listopada 1977 r. c. Di Felice, Monitor Ecclesiasticus 113 (1988), s. 224-237; dec. z dnia 18 listopada 1977 r. c. Serrano, Ephemerides Iuris Canonici 34 (1978) nr 2, s. 348-361; dec. $z$ dnia 12 lutego 1982 r. c. Pinto, Il Diritto Ecclesiastico 107 (1982) nr 4, s. 542543; dec. z dnia 4 lipca 1993 r. c. Serrano, Monitor Ecclesiasticus 119 (1994), s. 199208; dec. z dnia 16 grudnia 1994 r. c. Stankiewicz, Monitor Ecclesiasticus 122 (1997), s. 27-46; dec. z dnia 9 marca 1995 r. c. Stankiewicz, Monitor Ecclesiasticus 121 (1996), s. 475-493; dec. z dnia 31 maja 1995 r. c. Faltin, Monitor Ecclesiasticus 120 (1995), s. 508-525; dec. z dnia 31 stycznia 1997 r. c. Bruno, Monitor Ecclesiasticus 123 (1998), s. 196-246. 
jej braku do podjęcia istotnych obowiązków małżeńskich. Można zauważyć, że w tego rodzaju procesach powołani przez sądy kościelne biegli sądowi napotykają na wiele problemów, których pokonanie jest trudne, a czasami nawet niemożliwe w sprawie dostarczenia materialów dowodowych. $Z$ pewnością trudność ta polega na tym, że w procesach tych dochodzić trzeba prawdy wstecz i docierać do zdarzeń dość odległych w czasie.

Bardzo obszerne wypowiedzi na temat niezdolności do przyjęcia obowiązków małżeńskich z racji zaburzonej osobowości można znaleźć w wielu orzeczeniach sądów kościelnych ${ }^{20}$. Warto zaznaczyć, że stwierdzenie osobowości niedojrzałej $\mathrm{w}$ trakcie prowadzenia procesu kanonicznego o nieważność małżeństwa często odzwierciedla obec-

${ }^{20}$ Akta Sądu Biskupiego Lubelskiego (dalej ASBL): wyrok z dnia 7 stycznia 1990 r., nr akt 2659; wyrok z dnia 3 lutego1991 r., nr akt 2924; wyrok z dnia 30 marca 1991 r., nr akt 2952; wyrok z dnia 2 grudnia 1992 r., nr akt 3084; wyrok z dnia 29 maja 1993 r., nr akt 3192; wyrok z dnia 27 listopada 1994 r., nr akt 3275; wyrok z dnia 24 maja 1995 r., nr akt 3394; wyrok z dnia 6 maja 1996 r., nr akt 3371; wyrok z dnia 23 marca 1997 r., nr akt 3482; wyrok $z$ dnia 29 listopada 1998 r., nr akt 3448; wyrok $z$ dnia 18 kwietnia 1999 r., nr akt 3593; wyrok z dnia 30 stycznia 2000 r., nr akt 3551; wyrok z dnia 8 czerwca 2001 r., nr akt 3697; wyrok z dnia 29 sierpnia 2002 r., nr akt 3657; wyrok z dnia 3 grudnia 2003 r., nr akt 3790; wyrok z dnia 19 listopada 2004 r., nr akt 3871; wyrok z dnia 17 lipca 2005 r., nr akt 3836; wyrok z dnia 10 stycznia 2006 r., nr akt 3992; wyrok $z$ dnia 25 sierpnia 2007 r., nr akt 3946; wyrok z dnia 25 października 2008 r., nr akt 4016. Akta Sądu Metropolitalnego Warszawskiego (dalej ASMW): wyrok z dnia 28 kwietnia 1983 r., nr akt 11739; wyrok z dnia 16 maja 1984 r., nr akt 12926; wyrok z dnia 29 września 1985 r., nr akt 182/83; wyrok z dnia 12 stycznia 1986 r., nr akt 298/84; wyrok z dnia 27 października 1987 r., nr akt 352/85; wyrok z dnia 18 grudnia 1988 r., nr akt 380/85; wyrok z dnia 24 lutego 1989 r., nr akt 401/86; wyrok z dnia 30 marca 1990 r., nr akt 438/88; wyrok z dnia 18 czerwca 1991 r., nr akt 469/88; wyrok z dnia 27 marca 1992 r., nr akt 492/89; wyrok z dnia 27 kwietnia 1993 r., nr akt 499/88; wyrok z dnia 17 lipca 1994 r., nr akt 17392; wyrok z dnia 23 sierpnia 1995 r., nr akt 68 WPR; wyrok z dnia 29 października 1996 r., nr akt 74 WPR; wyrok z dnia 18 listopada 1997 r., nr akt 17382; wyrok z dnia 19 sierpnia 1998 r., nr akt 18349; wyrok z dnia 4 grudnia 1999 r., nr akt 18337; wyrok z dnia 5 lutego 2000 r., nr akt 19337; wyrok z dnia 9 sierpnia 2001 r., nr akt 19958; wyrok z dnia 15 listopada 2002 r., nr akt 499 WPR; wyrok z dnia 3 lipca 2003 r., nr akt 20337; wyrok z dnia 18 stycznia 2004 r., nr akt 20827; wyrok z dnia 8 czerwca 2005 r., nr akt 21659; wyrok z dnia 22 maja 2006 r., nr akt 529 WPR; wyrok z dnia 19 października 2007 r., nr akt 21994; wyrok z dnia 6 grudnia 2008 r., nr akt 22418; wyrok z dnia 29 listopada 2009 r., nr akt 22973; wyrok z dnia 7 maja 2010 r., nr akt 23461. 
ność zaburzenia już w okresie kojarzenia się małżeństwa, czasami natomiast może przesłaniać obraz faktyczny. W związku z tym zastanawiając się nad osobowością niedojrzałą w odniesieniu do podjęcia istotnych obowiązków małżeńskich należy zauważyć, że osoba z taką osobowością nie jest w stanie realizować istotnych obowiązków wypływających z zawartej umowy małżeńskiej. Jednocześnie warto zaznaczyć, że negatywne przejawy osobowości niedojrzałej uwidaczniają się w zawartym małżeństwie i to już od samego początku, w związku z czym małżonkowie nie są w stanie nawiązać ze sobą głębokiej więzi emocjonalnej.

\section{Osobowość niedojrzała a niezdolność do podjęcia i wypelnienia istotnych obowiązków małżeńskich}

W Kodeksie Prawa Kanonicznego z 1983 r. w kan. 1095 n. 3 umieszczono niezdolność osoby do podjęcia istotnych obowiązków małżeńskich, wskazując na przyczyny natury psychicznej (causa naturae psychicae $)^{21}$. Pojęcie dotyczące ,przyczyn natury psychicznej” należy rozpatrywać w odniesieniu do niezdolności osoby do przyjęcia przedmiotu zgody małżeńskiej. Według niektórych autorów termin ten należy rozumieć, jako zaburzenia ludzkiej psychiki, które powodują niepokonalne ograniczenia osoby wobec możliwości realizacji zobowiązań małżeńskich ${ }^{22}$. Inni autorzy zaś podkreślają, że zaburzenia ludzkiej psychiki są trudne do zbadania i usystematyzowania, chociażby z tego względu, że dotyczą sfery skomplikowanej bardziej niż zaburzenia fizjologiczne w aspekcie neurologicznym ${ }^{23}$. Zatem wynika z tego, iż niezdolność psychiczna do przyjęcia istotnych obowiązków małżeńskich zawarta w kan. 1095 n. 3 KPK z 1983 r. jest trudniejszym

${ }^{21}$ Por. A. GoŁęBiowska, Geneza kan. 1095 Kodeksu Prawa Kanonicznego Jana Pawła II, Prawo Kanoniczne 53 (2010) nr 3-4, s. 152-158; F. BersinI, Il diritto canonico matrimoniale, Commento giuridico - teologico - pastorale, Torino 1994, s. 99.

${ }^{22}$ Por. G. Versaldi, Elementa psichologica matrimonialis consensus, Periodica 71 (1982), s. 193; P. Bianchi, La causa naturae psichicae dell'incapacita, w: L'incapacita di assumere gli oneri essenziali del matrimonio, Citta del Vaticano 1998, s. 140.

${ }^{23}$ Por. O. Fumagalli Carulli, Perturbazioni psychice e consenso matrimoniale, Ephemerides Iuris Canonici 33 (1977), s. 71. 
tytułem nieważności od braku wystarczającego używania rozumu, który ustawodawca kościelny umieścił w n. 1 kan. 1095 oraz od poważnego braku rozeznania oceniającego co do istotnych praw i obowiązków małżeńskich wzajemnie przekazywanych i przyjmowanych wpisanego do n. 2 kan. 1095 z uwagi na zaburzenia natury emocjonalnej i wolitywnej, a nie intelektualnej.

Z analizy orzeczenia Roty Rzymskiej z dnia 17 lipca 1991 r. c. Bruno wynika, że udowodniono istnienie osobowości niedojrzałej, która posiadała wpływ na niezdolność do podjęcia istotnych obowiązków małżeńskich ${ }^{24}$. Ogromnie ważną sprawą było określenie wpływu takiej osobowości, którą określono, jako niedojrzałość emocjonalną a która miała wpływ na trwałość małżeństwa. Zgodnie z opinią ponensa pozwany - mężczyzna z osobowością niedojrzałą w zawartym małżeństwie $\mathrm{z}$ racji nadmiernej podejrzliwości nie był w stanie zawiązać trwałego przymierza małżeńskiego. W krótkim czasie po zawarciu małżeństwa miały miejsce bezpodstawne posądzenia współmałżonka, szczególnie o zdrady małżeńskie. Ponadto przeszkodą w nawiązaniu relacji interpersonalnych był wyraźnie zarysowany egoizm i egocentryzm, co w konsekwencji spowodowało, że istotnych obowiązków wynikających z dobra małżonków oraz potomstwa pozwany nie był w stanie zrealizować. Kolegium Sędziowskie wyjaśniło, że niedojrzałość emocjonalna w tym konkretnym przypadku wyrażała się brakiem zróżnicowania reakcji emocjonalnych zarówno w ich zbyt małym lub zbyt dużym natężeniu oraz słabej zdolności do przeżywania i przejawiania uczuć wyższych.

${ }^{24}$ Monitor Ecclesiasticus 117 (1992), s. 173. W analizowanym procesie pozwany mężczyzna posiadał osobowość zaburzoną niedojrzałą, która przejawiała się w chorobliwej zazdrości. Jednocześnie pozwany zeznał, iż z powodu zazdrości chciał sobie odebrać życie. Ponadto pozwany mężczyzna ujawniał ogromną podejrzliwość i nieufność wobec otoczenia, jak również posiadał skłonność do specyficznej i nieadekwatnej interpretacji faktów. Ta chorobliwa zazdrość wobec żony nie przeszkadzała pozwanemu dopuszczania się zdrad małżeńskich. Poza tym w niedługim czasie po ślubie okazało się, że został ojcem nieślubnego dziecka. Małżeństwo to przetrwało około 6 lat. 
W procesach kościelnych o nieważność małżeństwa dość często występuje osobowość niedojrzała, która czyni osobę niezdolną do podjęcia istotnych obowiązków małżeńskich ${ }^{25}$. Dotyczy to mężczyzn i kobiet. Wobec tego dokonując analizy procesów, w których została udowodniona nieważność małżeństwa z powodu osobowości niedojrzałej, można zauważyć, iż wiele przypadków tego typu osobowości połączonych jest z patologiczną atmosferą rodziny pochodzenia, czego przykładem jest wyrok Sadu Metropolitalnego Warszawskiego z dnia 10 stycznia $1991 r^{26}$. Jednocześnie należy nadmienić, iż przejawy zaburzeń zachowania w osobowości niedojrzałej są dość często tak duże, iż mężczyzna (kobieta) zmuszony jest do skorzystania z pomocy psychiatrycznej. W polskich sądach kościelnych liczba prowadzonych procesów o stwierdzenie nieważności małżeństwa z powodu osobowości niedojrzałej jest dość spora ${ }^{27}$.

${ }^{25}$ Por. S. Kosowicz, Niezdolność do relacji międzyosobowych (studium $w$ oparciu o wyroki rotalne okresu posoborowego), Radom 1988, s. 118.

${ }^{26}$ ASMW nr akt 492/88. W analizowanym procesie kościelnym pozwana z osobowością niedojrzałą wychowywała się w rodzinie, gdzie ojciec i matko byli alkoholikami. W młodości natomiast pozwana miała opinię „latawicy”, uciekała z domu, za co była bita przez ojca. Postępowanie przedślubne pozwanej powróciło zaraz po zawarciu małżeństwa. Już w cztery tygodnie po ślubie zdradzała męża. Poza tym mężowi nie okazywała czułości, miłości i odnosiła się do niego wulgarnie, traktując go, jak parobka. Z zeznań świadków wynika, że pozwana była osobą lekkomyślną, ciągle chciała gdzieś iść lub gdzieś jechać i żyła dniem dzisiejszym. Po rozpadzie małżeństwa, które przetrwało cztery miesiące już z żadnym mężczyzną nie zawiązała się na stałe. Miała także nieślubne dziecko. W ocenie świadków pozwaną cechowała nieodpowiedzialność i niezdolność przyznania się do popełnionego błędu. Jednocześnie pozwana nie była w stanie nawiązać głębokiej więzi z drugim człowiekiem, jak również nie rozumiała istoty małżeństwa. Wobec tego można powiedzieć, iż pozwana z osobowością niedojrzałą miała swoje podejście do małżeństwa i jego nierozerwalności. Ponadto jej poglądy zupełnie odbiegają od nauczania Kościoła katolickiego. W nawiązaniu nierozerwalności wspólnoty całego życia przeszkadzał pozwanej właśnie defekt psychiczny, który został określony przez biegłych sądowych, iż pozwana niezdolna jest do bliskich i wyłącznych więzi z jednym partnerem. Poza tym nierozerwalność małżeństwa nie jest dla pozwanej wartością, a wynika to $z$ doświadczeń, jakie wyniosła $z$ domu rodzinnego (rozbita rodzina) oraz ze środowiska, w którym żyła, a także z poziomu religijnego i intelektualnego.

${ }^{27}$ ASMW: wyrok z dnia 4 lutego 1984 r., nr akt 11983; wyrok z dnia 18 czerwca 
Przykładem rozstrzygnięcia sprawy o nieważność małżeństwa z tytułu psychicznej niezdolności do zawarcia małżeństwa i podjęcia istotnych obowiązków małżeńskich w wyniku osobowości niedojrzałej jest wyrok Sadu Metropolitalnego Warszawskiego z dnia 29 września $1994 r^{28}$. Kolegium Sędziowskie w uzasadnieniu wyroku skoncentrowało się na wyjaśnieniu tego, czy osoba z osobowością niedojrzałą jest w stanie realizować istotne obowiązki wypływające z zawartego

1985 r., nr akt 12663; wyrok z dnia 30 stycznia 1986 r., nr akt 185/83; wyrok z dnia 2 sierpnia 1987 r., nr akt 362/85; wyrok z dnia 16 czerwca 1988 r., nr akt 399/86; wyrok z dnia 25 maja 1989 r., nr akt 403/86; wyrok z dnia 10 stycznia 1990 r., nr akt 438/87; wyrok z dnia 27 lipca 1991 r., nr akt 495/87; wyrok z dnia 8 listopada 1992 r., nr akt 502/89; wyrok z dnia 14 stycznia 1993 r., nr akt 328/90; wyrok z dnia 23 lipca 1994 r., nr akt 538/91; wyrok z dnia 5 września 1995 r., nr akt 16392; wyrok z dnia 25 lutego 1996 r., nr akt 17339; wyrok z dnia 6 grudnia 1997 r., nr akt 69 WPR; wyrok z dnia 27 marca 1998 r., nr akt 18451; wyrok z dnia 18 maja 1999 r., nr akt 18994; wyrok z dnia 26 października 2000 r., nr akt 19337; wyrok z dnia 7 maja 2001 r., nr akt 369 WPR; wyrok z dnia 29 stycznia 2002 r., nr akt 20472; wyrok z dnia 12 sierpnia 2003 r., nr akt 20995; wyrok z dnia 25 marca 2004 r., nr akt 21449; wyrok z dnia 21 grudnia 2005 r., nr akt 21945; wyrok z dnia 30 stycznia 2006 r., nr akt 22552; wyrok z dnia 3 lipca 2007 r., nr akt 22994; wyrok z dnia 14 stycznia 2008 r., nr akt 23735; ASBL: wyrok z dnia 7 sierpnia 1996 r., nr akt 2321; wyrok z dnia 29 lipca 1997 r., nr akt 2391; wyrok z dnia 9 listopada 1998 r., nr akt 2459; wyrok z dnia 2 grudnia 1999 r., nr akt 2534; wyrok z dnia 15 września 2000 r., nr akt 2688; wyrok z dnia 23 listopada 2001 r., nr akt 2866; wyrok z dnia 28 marca 2002 r., nr akt 3021.

${ }^{28}$ ASMW nr akt 17231. W analizowanej sprawie mężczyzna pochodził z rozbitej rodziny a jego ojciec nadużywał alkoholu. Do zawarcia małżeństwa doszło na skutek przedślubnej ciąży. Ponadto pozwany decydując się na małżeństwo był przekonany, że podoła wszystkim obowiązkom małżeńskim. W związku z tym, że pierwsze tygodnie po zawarciu małżeństwa były dla pozwanego bardzo trudne, to wtedy właśnie wzrosło jego nadużywanie alkoholu. Pozwany posiadał zainteresowania muzyką. Był niesłowny i kłamliwy. Ponadto przejawiał skłonność do kobiet. Już miesiąc po ślubie chciał odejść od żony i nie chciał następnego dziecka, bo twierdził, że dziecko może wychowywać ulica. Według zeznań świadków przez półtora roku trwania małżeństwa miał kilka kochanek. Poza tym pozwany potrafił publicznie opowiadać o sprawach intymnych. W czasie trwania małżeństwa pozwany nie potrafił z niczego zrezygnować dla wspólnego dobra. Dla pozwanego ważny był tylko mecz, muzyka, koledzy, czy też alkohol. Poza tym znęcał się nad żoną fizycznie i psychicznie - pluł jej w twarz. Trudności ze współżyciem oraz opinie osób zaprzyjaźnionych z powódką upewniły ją w przekonaniu, że pozwany nie jest w stanie nawiązać więzi interpersonalnej i wspólnoty życia małżeńskiego. 
związku małżeńskiego. Ponadto Kolegium Sędziowskie zaznaczyło, że negatywne przejawy osobowości niedojrzałej w sposób dość widoczny uwydatniały się w zawartym małżeństwie, dlatego też od samego początku nie rokowało ono na przetrwanie. Tak więc osoba z osobowością niedojrzałą nie jest w stanie nawiązać głębokiej więzi z drugą osobą. W konkluzji wyroku Kolegium Sędziowskie przedstawiło dyferencje zachodzące w sformułowaniu kan. 1095 nn. 1-2 oraz kan. 1095 n. 3 KPK z 1983 r. Jednocześnie wskazano, że w dwóch pierwszych tytułach ustawodawca kościelny uwydatnił kwestię znaczenia aktu psychologicznego zgody małżeńskiej. Z kolei w numerze trzecim położył nacisk na sprawę niemożliwości podjęcia i wypełnienia przedmiotu zgody małżeńskiej ${ }^{29}$.

W wyroku Sadu Metropolitalnego Warszawskiego z dnia 30 marca $1995 r$. Kolegium Sędziowskie stwierdziło, że pozwana posiadające osobowość niedojrzałą nie jest w stanie budować relacji interpersonalnych, co niewątpliwie w małżeństwie jest kwestią dość istotną ${ }^{30}$. W orzeczeniu zaznaczono także, że pozwana z osobowością niedojrzałą zauważa tylko swoje potrzeby, natomiast dobro współmałżonka i potomstwa zupełnie ją nie interesuja. W związku z tym osobowość niedojrzała uniemożliwia jej podjęcie istotnych obowiązków względem bonum coniugum oraz bonum prolis.

${ }^{29}$ Por. M. FĄKA, Niezdolność do przyjęcia istotnych obowiqzków matzeńskich jako tytuł nieważności małżeństwa, Prawo Kanoniczne 25 (1982) nr 1-2, s. 245-269.

${ }^{30}$ ASMW nr akt 65 WPR. W analizowanej sprawie pozwana z osobowością niedojrzałą wychowywała się w rodzinie, w której matka była bardzo nieczuła, wręcz chłodna emocjonalnie. Z kolei ojciec pozwanej nie miał kontaktów z żoną i z dziećmi. Ponadto wszyscy odczuwali lęk przez ojcem. Pozwana przed zawarciem małżeństwa przerwała studia, ponieważ zakochała się w pewnym mężczyźnie. Wychodząc za mąż, chciała zaś zrobić na złość swoim rodzicom. Po ślubie okazało się, że pozwana nie zamieszkała razem z mężem, tylko dochodziła do niego. Po dwóch latach zerwała w ten sposób wspólnotę małżeńską. Biegły sądowy rozpoznał u pozwanej osobowość niedojrzałą i wskazał, że zaburzenie to posiadało wpływ na istnienie głębokiego napięcia psychicznego oraz silne reakcje lękowe, a także poczucie nierealności siebie i braku kontroli nad własnym zachowaniem; Zob. A. GoŁĘBıowsKa, Forma wykluczenia bonum prolis $w$ doktrynie i orzecznictwie Roty Rzymskiej, Ius Matrimoniale 17 (23), Warszawa 2012, s. 65-84. 
W innym wyroku Roty Rzymskiej z dnia 26 lipca 1997 r. c. Bruno przedstawiono stwierdzenie, że pozwany posiadający osobowość niedojrzałą do realizacji poszczególnych istotnych obowiązków wynikających z zawartego małżeństwa nie jest $\mathrm{w}$ stanie realizować dobra potomstwa $^{31}$. Ponadto Kolegium Sędziowskie wyjaśniło, że u pozwanego nie dostrzega się pozytywnych zachowań wobec własnego dziec$\mathrm{ka}$, bowiem pozwany posiadał brutalny stosunek przed i po urodzeniu dziecka. Kolegium Sędziowskie w konkluzji orzeczenia zaznaczyło, że pozwany z osobowością niedojrzałą kieruje się egoizmem i nie chce zaakceptować faktu, iż jest ojcem dziecka. W związku z tym nie jest w stanie podjać istotnego obowiązku, jakim jest wychowanie potomstwa. Z opinii niektórych autorów wynika, że niedojrzałość społeczna i psychiczna jednej nawet ze stron przejawia się na co dzień w braku uświadomienia sobie podjętych zobowiązań i obowiązków oraz braku przygotowania do ich wypełnienia ${ }^{32}$. Wszystko to uwidacznia się

${ }^{31}$ Monitor Ecclesiasticus 123 (1998), s. 196-246. W analizowanej sprawie pozwany posiadał swoją „filozofię”, gdyż uważał, że ślub kościelny nie uszczęśliwia człowieka, a tylko mu przeszkadza. Do małżeństwa jednak doszło, ponieważ narzeczona była w ciąży, z czego pozwany nie był zadowolony. Zdaniem pozwanego kobieta jest człowiekiem drugiej klasy - przeznaczona tylko do pracy. Siebie natomiast pozwany uważał za nieomylnego, żył dniem dzisiejszym i nadużywał alkoholu. Kiedy powódka była w ciąży pozwany znęcał się nad nią fizycznie. Ponadto pozwany w tym czasie pojechał z drugą kobietą na wczasy. Pozwany nie poczuwał się do obowiązku wychowania dziecka. $Z$ kolei po rozpadzie małżeństwa pozwany nie utrzymuje kontaktu z dzieckiem, co niekorzystnie odbiło się na kształtowaniu osobowości potomstwa. Z zeznań świadków wynika, że pozwany wyrażał się, iż brzydzi się dziecka do ukończenia pierwszego roku. $\mathrm{Z}$ akt procesu wynika, że biegły sądowy stwierdził, że pozwany posiada niedorozwój sfery uczuciowości wyższej i podkreśla swoje ,ja”.

${ }^{32}$ Por. P. Wesemann, Psychiczna niezdolność do matżeństwa jako problem sqdownictwa kościelnego, Kościół i Prawo, t. 3, Lublin 1984, s. 82; S. Steuden, Osobowościowe uwarunkowania niepowodzenia w małżeństwie, w: Małżeństwo - przymierze miłości, (red.) J. Misiurek, W. Słomka, Lublin 1995, s. 206. Autor wyjaśnia, że przejawem niedojrzałości związanej z młodym wiekiem może być pochopne podjęcie decyzji o zawarciu małżeństwa. Poza tym Autor zwraca uwagę na to, iż krótka i powierzchowna znajomość partnera jest z pewnością nie wystarczająca. Temu wszystkiemu może także towarzyszyć niewiedza na temat istoty małżeństwa i związanych z nim wzajemnych praw i obowiązków, jak również brak podstawowych doświadczeń życiowych, dotyczących prowadzenia gospodarstwa domowego. 
w infantylizmie wyrażającym się w sposobie traktowania małżeństwa i rodziny, jak również w przygotowaniu do współżycia i współdziałania w układach mąż - żona. $Z$ analizy akt procesów kościelnych orzekających niezdolność osoby do podjęcia istotnych obowiązków małżeńskich z przyczyn natury psychicznej wynika, że osoby zbyt młode łatwo zawierają małżeństwo, chociaż nie są dojrzali wewnętrznie i nie są w pełni świadomi swej odpowiedzialności, stąd też nie potrafią udźwignąć ciężaru jego trwałości ${ }^{33}$.

Dla stwierdzenia nieważności małżeństwa zgodnie z kan. 1095 n. 3 KPK z 1983 r. należy wskazać, że stan psychicznej niezdolności istniał przed lub w momencie zawierania małżeństwa. Nie wystarczy natomiast samo potwierdzenie takiego stanu, ponieważ istotne jest, aby jego nasilenie uniemożliwiło tworzenie wspólnoty małżeńskiej i nawiązanie relacji wyłącznej tylko z drugą osobą ${ }^{34}$. Z analizy akt wyroku Sadu Biskupiego Lubelskiego z dnia 19 maja 1997 r. ${ }^{35}$, wynika,

${ }^{33}$ ASMW: wyrok z dnia 29 stycznia 1984 r., nr akt 11293; wyrok z dnia 3 lutego 1985 r., nr akt 95/83; wyrok $z$ dnia 26 listopada 1986 r., nr akt 11993; wyrok $z$ dnia 8 czerwca 1987 r., nr akt 59/85; wyrok z dnia 30 listopada 1988 r., nr akt 387/85; wyrok z dnia 14 grudnia 1989 r., nr akt 492/86; wyrok z dnia 16 maja 1990 r., nr akt 532/88; wyrok z dnia 27 marca 1991 r., nr akt 572/88; wyrok z dnia 21 sierpnia 1992 r., nr akt 16992; wyrok z dnia 25 czerwca 1993 r., nr akt 534/90; wyrok z dnia 5 sierpnia 1994 r., nr akt 16922; wyrok z dnia 30 maja 1995 r., nr akt 94 WPR; wyrok z dnia 29 września 1996 r., nr akt 17339; wyrok z dnia 24 marca 1997 r., nr akt 63 WPR; wyrok z dnia 19 grudnia 1998 r., nr akt 17947; wyrok z dnia 7 czerwca 1999 r., nr akt 18339; wyrok z dnia 27 stycznia 2000 r., nr akt 18730; wyrok z dnia 15 października 2001 r., nr akt 19226; wyrok z dnia 2 września 2002 r., nr akt 20244; wyrok z dnia 30 listopada 2003 r., nr akt 20871; wyrok z dnia 17 marca 2004 r., nr akt 21339. ASBL: wyrok z dnia 3 marca 1994 r., nr akt 2190; wyrok z dnia 27 stycznia 1995 r., nr akt 2236; wyrok z dnia 24 czerwca 1996 r., nr akt 2296; wyrok z dnia 30 maja 1997 r., nr akt 2373; wyrok z dnia 6 grudnia 1998 r., nr akt 2475; wyrok z dnia 28 maja 1999 r., nr akt 2533; wyrok z dnia 10 stycznia 2000 r., nr akt 2643; wyrok z dnia 7 lipca 2001 r., nr akt 2971.

${ }^{34} \mathrm{D}$. DE CARO, La cosidetta , incapacita psicologica in riferimento alla validita del consenso matrimoniale second oil diritto canonico, Monitor Ecclesiasticus 108 (1983), s. 223; A. McGrath, On the Gravity of Causes of a Psychological Nature in the Proof of Inability to Assume the Essential Obligationes of Marriage, Studia Canonica 22 (1988), s. 68.

${ }^{35}$ ASBL nr akt. 3492. W analizowanej sprawie pozwany z rozpoznaną osobowością niedojrzałą zanim zawarł związek małżeński wcześniej przez pewien czas przebywał 
że osobowość niedojrzała w relacji do podjęcia istotnych obowiązków małżeńskich nie pozwoliła na zawiązanie dogłębnej wspólnoty życia. Poza tym w konkluzji wyroku zaznaczono, że pozwany nie potrafił patrzeć przez pryzmat „my”, tylko przez ,ja” i z tego względu nie był w stanie podjąć obowiązków względem powódki. Kolegium Sędziowskie podkreśliło, że sytuacja taka nie wynika ze złej woli pozwanego, tylko z racji osobowości niedojrzałej. Ponadto wyjaśniono, że osobowość niedojrzała doprowadziła pozwanego do niezdolności do podjęcia istotnych obowiązków małżeńskich, a przede wszystkim do nawiązania z powódką trwałej więzi interpersonalnej.

Z analizy orzeczenia Sadu Metropolitalnego Warszawskiego z dnia 14 sierpnia $1999 r^{36}$ wynika, że akta procesów kanonicznych o nieważność małżeństwa potwierdzają badania naukowe nad osobowością niedojrzała. Z konkluzji wyroku wynika, że pozwany posiadający osobowość niedojrzałą nie jest zdolny do tworzenia relacji interpersonal-

w zakonie, Jego przełożeni jednak stwierdzili, iż nie nadaje się on na zakonnika z racji trudnego charakteru. Z kolei zawierając małżeństwo pozwany miał już 46 lat. Powódka określiła pozwanego, jako człowieka dziwnego, gdyż po ślubie mówił, że ją zabije, a sam się powiesi. Pozwany nigdzie nie pracował, całymi dniami siedział ubrany w piżamie i twierdził, że odpędza szatana. Te dziwne zachowania pozwanego nasiliły się, gdy w małżeństwie doszła odpowiedzialność za drugiego człowieka (za żonę). Ponadto pozwany przejawiał cechy osobowości sztywnej. Miał także trudności z dostosowaniem się do zmiennych sytuacji życiowych. Pozwany nie uwzględniał możliwości współmałżonki. Zachowanie pozwanego, jak i cechy jego osobowości doprowadziły do spięć z powódką. Osobowość niedojrzała, jaką posiadał pozwany uniemożliwiła mu stworzenie faktycznej wspólnoty małżeńskiej oraz głębokich więzów emocjonalnych, które wykraczały poza obszar własnego ,ja”.

36 ASMW nr akt 16227. W analizowanej sprawie pozwany wychowywał się w rodzinie, w której ojciec przebywał w więzieniu. Z kolei sam pozwany, jako dziecko sprawiał trudności wychowawcze, bowiem do matki odnosił się z przekleństwami. Pozwany jeszcze przed ślubem przejawiał niezrównoważone zachowania, ponieważ przyszłą żonę szantażował samobójstwem, w sytuacji, gdy ona nie wyrazi zgody na małżeństwo. Jednakże w dość krótkim czasie po zawarciu małżeństwa pozwany zaczął odchodzić od żony - w ciagu dwóch lat odchodził kilka razy. Z zeznań świadków zaś wynika, że pozwany jest niezrównoważony, nie umiejący zrezygnować z własnych zachcianek. Ponadto stwierdzono, że jest egoista, osobą dostającą „obłędnego szału”. Poza tym pozwany okazał się osobą niezwykle emocjonalną i niezwykle krytyczną wobec siebie. 
nych. Kolegium Sędziowskie podkreśliło, że pozwany w zawartym małżeństwie widział jedynie swoje potrzeby i dlatego od samego początku małżeństwo to było nieudane i trwało krótko, co w rzeczywistości uniemożliwiło pozwanemu na zawiązanie więzi interpersonalnej z powódką.

Zatem istnieje wattpliwość i należy postawić pytanie: czy faktycznie osoba, u której stwierdzono niezdolność posiadała niedojrzałość emocjonalną? Z analizy akt procesów kościelnych wynika, że wiele razy została orzeczona nieważność małżeństwa, gdy nie występowały u osób żadne zaburzenia psychiczne. Niektórzy autorzy natomiast wyjaśniaja, że ma to miejsce wówczas, gdy została stwierdzona osobowość niedojrzała, chociażby ze względu na młody wiek ${ }^{37}$. Z tego też względu osoba taka nie była zdolna podjąć istotnych obowiązków małżeńskich nie z powodu istnienia anomalii psychicznych, ale z racji ciaggle trwającego etapu dojrzewania osobowości. Niektórzy autorzy wyjaśniają, że nie wystarczy wypowiadać się tylko o samym pojęciu niedojrzałości, jako kryterium oceny niezdolności do ważnego zawarcia małżeństwa ${ }^{38}$. Wobec tego zasadnym wydaje się określenie punktu krytycznego tej niezdolności, poniżej której niedojrzałość czyni osobę niezdolną do ważnego zawarcia umowy małżeńskiej, czyli do podjęcia się zobowiązań małżeńskich i jednocześnie realizacji tej umowy, a więc wypełnienia tych zobowiązań. Tak więc w taki sposób rozumianą niedojrzałość można uznać za przeszkodę do ważnego zawarcia małżeństwa.

Z analizy procesów kościelnych orzekających niezdolność osoby do podjęcia istotnych obowiązków małżeńskich dość często wynika, że czasami obie strony posiadają osobowość niedojrzałą i w związku z nią podkreśla się defectus libertatis internae. Występuje to w sytuacji wczesnego wyboru partnera i zawarcia małżeństwa, czego przykładem

${ }^{37}$ Por. R. Sztychmiler, Problem określenia istotnych obowiqzków matzeńskich, w: Ius Matrimoniale, t. 1 (6-7), Warszawa 1996, s. 75; M. JArosz, Podstawy psychiatrii, Warszawa 1988, s. 272.

${ }^{38}$ Por. P. Wesemann, Psychiczna niezdolność do matżeństwa ..., s. 84; W. Prężyna, Problem psychologicznych kryteriów..., s. 108; S. STEUdEn, Osobowościowe uwarunkowania..., s. 109. 
może być wyrok Sadu Biskupiego Lubelskiego z dnia 27 czerwca 2000 r. ${ }^{39}$. Kolegium Sędziowskie zaznaczyło, że oceniając zachowanie stron procesowych, jako osób niepełnoletnich należy odróżnić osobowość niedojrzałą od osobowości zaburzonej, jaką przejawiali zawierając małżeństwo sakramentalne. W konkluzji wyroku wyjaśniono, że jednym z objawów osobowości niedojrzałej jest właśnie brak zdolności dokonania własnego wyboru.

Jednocześnie nasuwa się następna wątpliwość i dlatego należy postawić pytanie, czyli: jak rozróżnić termin „niezdolności w ogóle” od terminu „niezdolności w ujęciu procesowym”? Odpowiadając na tę wątpliwość zasadnym wydaje się wskazanie, że pojęcie „niezdolności w ogóle" oznacza niezdolność do wejścia we wspólnotę małżeńską w relacji do wszystkich potencjalnych partnerów i to niezależnie od ich osobowości. Zatem dotyczy takiego zespołu cech osobowości człowieka, który czyni go absolutnie niezdolnym do relacji małżeńskiej z jakimkolwiek partnerem płci przeciwnej. Wobec tego można powiedzieć, że niezdolność do podjęcia istotnych obowiązków małżeńskich, czyli do wspólnoty osób powinno być odnoszone do konkretnego badanego związku małżeńskiego. W związku z tym można wypowiadać się tutaj o „niezdolności w ujęciu procesowym”, czyli faktycznie istniejącej i koniecznie ujawniającej się niezdolności, z tym, że orzekaną w kontekście już konkretnego związku małżeńskiego, w którym niezdolność ta ujawniła się ${ }^{40}$.

${ }^{39}$ ASBL nr akt 3624. W analizowanej sprawie pozwana miała 17 lat kiedy doszło do zawarcia małżeństwa i to na skutek ciąży. W trakcie małżeństwa nadużywała alkoholu i zdradzała męża. Podczas zeznań świadków doszło do wyjaśnienia postępowania pozwanej, która według nich posiadała „dziecinny rozum”. Z kolei powód, jako niepełnoletni mężczyzna zawarł małżeństwo w wieku 20 lat. Pochodził z rozbitej rodziny i był jedynakiem. Matka była w nim zakochana i traktowała go, jak małe dziecko. Powód nie miał własnego zdania. Świadkowie określili powoda, jako „maminsynka”, który był całkowicie uzależniony od rodziców. Poza tym powód nie potrafił z pozwaną stworzyć odrębnej wspólnoty małżeńskiej. Zarobione pieniądze oddawał nie pozwanej, tylko matce. Małżeństwo stron przetrwało około roku. Podczas zeznań powód zeznał, że zawarł małżeństwo nie z miłości, ale pod wpływem matki, która namówiła go do tego, bo pozwana była w ciąży.

${ }^{40}$ Por. W. KRUPA, Zasady opracowywania opinii biegłego psychologa w sprawach 
Warto również dokonać analizy wyroku Sqdu Biskupiego Lubelskiego z dnia 24 czerwca $2001 r^{41}$, gdzie w konkluzji wyroku zaznaczo-

o nieważność matżństwa, w: Ius Matrimoniale, t. 1 (6-7), Warszawa 1996, s. 141; S. KoŁaKowsKi, Ocena psychicznej zdolności do zawarcia małżeństwa, w: Wobec osób zaburzonych psychicznie, Kraków 1996, s. 264. Autorzy są zdania, że psychiczna niezdolność do prowadzenia życia małżeńskiego wynika z zaburzenia psychicznego, jak również może zależeć od czynników zewnętrznych. Wobec tego osoba może być niezdolna do pożycia małżeńskiego w konkretnym układzie partnerskim lub rodzinnym. W związku z tym sposób interpretowania punktu 3 kan. 1095 KPK z 1983 r. powinien być przeprowadzony bardzo ostrożnie, aby nie doszło do niebezpiecznych nadużyć, szczególnie przy niezgodności charakterów małżonków. Zob. R. SzTYcHMILER, Problem określenia istotnych..., s. 75. Autor podkreśla, że przy udowodnieniu nieważności małżeństwa z tytułu niezdolności do podjęcia i wypełnienia istotnych obowiązków małżeńskich konieczne jest ustalenie trzech elementów, czyli: po pierwsze, czy podejrzana osoba cierpi na konkretne, ustalone przez sędziego lub biegłego zaburzenie psychiczne, a po drugie, czy z racji tego zaburzenia osoba nie była zdolna podjąć się wypełnienia przynajmniej jednego z istotnych obowiązków, nie wystarczy, aby zaburzenie powodowało tylko utrudnienie, ale musi ono powodować niemożność wypełnienia jakiegoś obowiązku i po trzecie natomiast, czy zaburzenie to i wynikająca niego niezdolność istniała już w chwili zawierania małżeństwa. Autor wyjaśnił także, iż przyczyny natury psychicznej nie można identyfikować z anomalią psychiczną. Zob. W. Góralski, Niezdolność do podjęcia istotnych obowiazków matżeńskich, w: Przymierze małżeńskie, Lublin 1993, s. 40. Autor wyjaśnił, że w kwestii absolutności i względności niezdolności jest zdania, iż należy w sposób zdecydowany opowiedzieć się za przymiotem absolutności. Jednocześnie dodał, że nie należy wymagać takiego przymiotu, ponieważ pojęcie niezdolności do podjęcia istotnych obowiązków małżeńskich zakłada, że chodzi o relację nupturienta do tych obowiązków, a nie do osoby współpartnera. Autor podkreślił również, że: „doszukiwanie się jakichkolwiek przymiotów niezdolności do podjęcia istotnych obowiązków małżeńskich, jakkolwiek jest pożyteczne i w pełni usprawiedliwione $\mathrm{z}$ punktu widzenia pragmatyki, to jednak w wymiarze czysto spekulatywnym pozostaje czymś zbędnym. Incapacitas assimendi jest po prostu niezdolnością podmiotu występującego hic et nunc w odniesieniu do pojęcia (i wypełnienia) istotnych powinności małżeńskich".

${ }^{41}$ ASBL nr akt 2945. W analizowanej sprawie u pozwanej stwierdzono osobowość niedojrzałą. Podczas zeznań powód opisał pozwaną jako niezdolną do nawiązania trwałych i pozytywnych kontaktów z ludźmi, jak również określił ją, jako niezdolną do radzenia sobie w sytuacjach dość trudnych. Ponadto zaznaczył, iż u pozwanej występowały napady padaczki, co zresztą zostało udowodnione poprzez przedstawienie dokumentacji lekarskiej. Biegły psycholog natomiast dopatrzył się u pozwanej źródła osobowości niedojrzałej, które przerastały jej odporność psychiczną, co uniemożliwiło jej zawiązanie odrębnej wspólnoty małżeńskiej. 
no, że pozwaną cechuje zmienność i nieuporządkowanie emocjonalne, które objawia się śmiechem lub płaczem oraz łatwym przyjmowaniem postawy agresywnej lub biernej. Kolegium Sędziowskie wyjaśniło, iż tego typu zachowanie pozwanej doprowadziło do tego, iż nie jest ona w stanie podjąć istotnego obowiązku małżeńskiego, jakim jest jedność i nierozerwalność sakramentu małżeństwa.

Rozważając wszelkie sytuacje zawarte w aktach procesów kościelnych dotyczących spraw o stwierdzenie nieważności małżeństwa, zwłaszcza rozpatrywanych z kan. 1095 n. 3 KPK z 1983 r. należy zwrócić uwagę na rolę, jaką odgrywa powoływany w procesie biegły sądowy - psychiatra lub psycholog. W jurysprudencji kościelnej natomiast zauważa się ewolucję w kwestii traktowania różnego rodzaju zakłóceń osobowościowych, jako przyczyny nieważności małżeństwa. Tak więc to nowe spojrzenie doprowadza do przyjęcia koncepcji, w myśl której określone rodzaje patologii przede wszystkim z dziedziny psychoseksualnej, powodujące niezdolność do podjęcia istotnych obowiązków małżeńskich, należy traktować, jako odrębny tytuł nieważności ${ }^{42}$. Z pewnością sędziowie rotalni posiadają świadomość trudności, jaką sprawia określenie tego, co w stosunkach małżeńskich jest „normalne", a to jest konieczne, aby rozstrzygać o tym, czy zachowanie stron procesowych było na tyle ,nienormalne”, iż spowodowało nieważnie wyrażoną zgodę małżeńską.

W dalszym ciagu analizując poszczególne procesy kościelne orzekające niezdolność osoby do podjęcia istotnych obowiązków małżeńskich z przyczyn natury psychicznej można zauważyć, w jaki sposób osobowość niedojrzała kobiety przejawia się w jej funkcjonowaniu w roli żony i matki a także, jakie istotne obowiązki małżeńskie nie mogą być przez nią podjęte i zrealizowane w trakcie trwania małżeństwa. Przykładem może być wyrok Sqdu Metropolitalnego Warszawskiego z dnia 26 listopada 2003 r., gdzie udowodniono nieważność

${ }^{42}$ W. GóRAlski, Problem nieważności umowy matżeńskiej z tytułu niezdolności do podjęcia i wypetnienia zobowiazań małżeńskich, Kościół i Prawo, t. 4, Lublin 1985, s. 195. 
małżeństwa z powodu zaburzeń w sferze psychoseksualnej ${ }^{43}$. W orzeczeniu wyroku Kolegium Sędziowskie wyjaśniło, że pozwana posiadająca osobowość niedojrzałą posiada nieuporządkowany popęd seksualny i to silniejszy od składanych przyrzeczeń wierności małżeńskiej, tak więc jej niedojrzała osobowość uniemożliwia jej realizację dobra wierności małżeńskiej.

Z kolei w wyroku Sqdu Metropolitalnego Warszawskiego z dnia 2 lipca 2004 r. zaznaczono, że pozwaną charakteryzuje znaczna niedojrzałość psychiczna ${ }^{44}$. W związku z tym Kolegium Sędziowskie podkreśliło, że pozwana nie jest w stanie zawiązać odrębnego i trwałego przymierza małżeńskiego do tego stopnia, że jej zależność od rodziny pochodzenia okazała się silniejsza od dobra małżeństwa i współmałżonka. Zaznaczono również, iż niedojrzałość emocjonalna pozwanej

${ }^{43}$ ASMW nr akt 20371. W przytaczanym procesie kobieta z rozpoznaną osobowością niedojrzałą była jedynaczką. Z kolei po zawarciu małżeństwa nadużywała alkoholu, jak również nie dbała o męża, a także nie podejmowała pracy zawodowej. Poza tym nie wypełniała żadnych innych obowiązków małżeńskich, które głównie należą do żony. Dochodziło do tego, że przez całe tygodnie nie odzywała się do męża, pomimo tego, że małżeństwo trwało około dwóch lat. W krótkim czasie po ślubie zaś przestała dochowywać wierności swojemu mężowi, zdradzała go nawet z jego bratem. Ponadto pozwana posiadała bezosobowy stosunek do współżycia fizycznego. Z zeznań świadków wynika, że pozwana opowiadała, że nie sprawia jej różnicy, z kim współżyje. Świadkowie natomiast określili pozwaną, jako osobę lekkomyślną, egoistkę, despotkę pustą nerwową i leniwą. Uważali również, że wyszła za mąż, aby „mieć zasłonę przed swoimi wyczynami”.

${ }^{44}$ ASMW nr akt 21554. W analizowanej sprawie pozwana jest całkowicie uzależniona od matki. Pozwana pochodziła z rodziny rozbitej. W młodości była bardzo nerwowa, chwiejna i niezrównoważona. Ze swoją matką żyły, jak ,siostry”. Świadkowie zeznali, że pozwana miała taki sam charakter, jak jej matka. Po zawarciu małżeństwa zdanie matki było dla niej ważniejsze od zdania męża. Pozwana wszystko lekceważyła, nie gotowała obiadów, nie przygotowywała innych posiłków, nie sprzątała, ale często wyjeżdżała z domu. Poza tym pozwana dopuszczała się zdrad, a według relacji świadków miała pokazywać pieniądze, które otrzymywała z nierządu. Ponadto pozwana twierdziła, że będzie robiła to, co jej się podoba i na co będzie miała ochotę. W tym wszystkim miała wsparcie swojej matki. Kochanek przyjeżdżał do matki i do córki. Małżeństwo to przetrwało około dwóch lat. Biegły sądowy - psycholog w swojej opinii stwierdził u pozwanej osobowość niedojrzałą typu zależnego z niedojrzałością w sferze emocjonalno-popędliwej. 
spowodowała jej niezdolność do tworzenia relacji interpersonalnych, a tym samym do zawiązania trwałego przymierza małżeńskiego.

W wyroku Sadu Metropolitalnego Warszawskiego z dnia 23 września 2005 r. wyjaśniono, że pozwany z powodu nadmiernej podejrzliwości nie był w stanie zawiązać trwałego przymierza małżeńskiego $^{45}$. Kolegium Sędziowskie zaznaczyło, że bezpodstawne posądzanie współmałżonka, szczególnie o zdrady małżeńskie stanowią przeszkodę w nawiązaniu relacji interpersonalnych, a to w konsekwencji powoduje, iż istotnych obowiązków wynikających z dobra małżonków oraz potomstwa pozwany z osobowością niedojrzałą nie jest w stanie zrealizować.

Z analizy wyroku Sqdu Metropolitalnego Warszawskiego z dnia 30 czerwca 2006 r., wynika, że pozwany z osobowością niedojrzałą przejawia niepewność i stale nawracające wątpliwości, z czym łączy się trudność w podejmowaniu decyzji ${ }^{46}$. Kolegium Sędziowskie oceniając osobowość pozwanego w relacji do podjęcia istotnych obowiązków małżeńskich stwierdziło, że w zawartym małżeństwie jego

${ }^{45}$ ASMW nr akt 21883. W analizowanym procesie pozwany z osobowością niedojrzałą był „maminsynkiem” rozpieszczanym przez matkę. Wobec zaistniałych trudności miał myśli samobójcze. Ponadto był wielkim egoistą, co okazało się po urodzeniu dziecka. Poza tym pozwany nie okazywał zainteresowania narodzonym dzieckiem, a nawet usuwał je ze swojego życia. Z zeznań świadków wynika, że pozwany jest osobą nieufną i podejrzliwą. Z kolei powołany biegły sądowy - psycholog stwierdził, że pozwany posiada osobowość niedojrzałą z cechami paranoicznymi, a jego zachowanie ocenił następującymi cechami: podejrzliwość, obwinianie otoczenia za doznane porażki, wyręczanie się rodzicami przy załatwianiu spraw, preferowanie wartości materialnych.

${ }^{46}$ ASMW nr akt 23491. W przytaczanej sprawie pozwany z rozpoznaną osobowością niedojrzałą, zanim zawarł związek małżeński, wcześniej przez dwa lata przebywał w więzieniu. Zawierając małżeństwo miał 39 lat. Powódka zaś określiła pozwanego, jako osobę dziwną, ponieważ mówił wiele razy, że ją zabije lub udusi, a sam popełni samobójstwo. Ponadto pozwany nigdzie nie pracował i całymi dniami siedział w domu. Objawy dziwnego zachowania nasiliły się, gdy urodziło się dziecko. Wtedy pozwany przejawiał cechy osobowości sztywnej i miał trudności z dostosowaniem się do zmiennych sytuacji życiowych, w tym konkretnym przypadku przyjście na świat dziecka uniemożliwiło stworzenie faktycznej wspólnoty małżeńskiej i nawiązania więzów emocjonalnych z żoną i dzieckiem. 
osobowość nie pozwoliła na zawiązanie dogłębnej wspólnoty życia. W konkluzji wyroku zaznaczono, że pozwany posiadający osobowość niedojrzałą nie potrafi patrzeć przez „my”, a tylko przez ,ja”. W związku z tym stwierdzono, że pozwany nie jest w stanie podjąć obowiązków względem współmałżonki i nie wynika to z jego złej woli, ale z niedojrzałej osobowości. Ponadto zaznaczono, że zaburzone zachowania pozwanego uczyniły go niezdolnego do podjęcia istotnych obowiązków małżeńskich, zwłaszcza w kwestii nawiązania z drugą osobą trwałej więzi interpersonalnej.

Zastanawiając się nad oceną osobowości niedojrzałej w relacji do podjęcia istotnych obowiązków małżeńskich można wskazać na wyrok Sqdu Metropolitalnego Warszawskiego z dnia 18 listopada 2007 r., gdzie osoba z osobowością niedojrzałą nie była zdolna do tworzenia relacji interpersonalnych, z uwagi na to, że nie była w stanie okazać współmałżonkowi uczuć ${ }^{47}$. W konkluzji wyroku Kolegium Sędziowskie wyjaśniło, że pozwany w małżeństwie widział tylko swoje potrzeby i cechuje go egoizm. Dlatego też istniejąca u pozwanego osobowość niedojrzała uniemożliwiła mu zawiązanie więzi interpersonalnych z partnerem małżeńskim.

$\mathrm{Z}$ analizy procesów kościelnych orzekających nieważność małżeństwa $z$ tytułu niezdolności osoby do podjęcia istotnych obowiązków małżeńskich wynika, że dość często można spotkać się z rozpoznaniem osobowości niedojrzałej. Występuje to najczęściej wtedy, gdy osoba zawierająca małżeństwo spełnia wymóg prawa kościelnego w kwe-

${ }^{47}$ ASMW nr akt 24329. W analizowanej sprawie pozwany z osobowością zaburzoną niedojrzałą był egoistyczny, agresywny i dbał tylko o swoje interesy oraz przyjemności. Dla pozwanego miłość to tylko seks, tak więc dochodziło do tego, że żądał od żony współżycia kilkanaście razy na noc. Poza tym nie interesował go dom, natomiast wolał przebywać w towarzystwie kolegów. Z zeznań świadków wynika, że pozwany okazał się człowiekiem dziwnym w zachowaniu. Stwierdzono także, że jest oschły dla żony i z tego co słyszeli znęcał się nad nią moralnie. Małżeństwo stron przetrwało dwa i pół roku. Powołany w procesie biegły sądowy - psycholog zwrócił uwagę na takie cechy charakteru pozwanego jak: wybuchowość, drażliwość, konfliktowość, przejawianie nadmiernej aktywności seksualnej oraz niemożliwość radzenia sobie w sytuacjach trudnych. Biorąc to wszystko pod uwagę stwierdzono, że małżeństwo to od samego początku było nieudane i trwało krótko. 
stii wieku do ważnego zawarcia małżeństwa, ale jest niepełnoletnia w świetle przepisów prawa cywilnego. Wobec tego należy wyjaśnić, że przeszkoda braku wieku (impedimentom aetatis) występuje wówczas, gdy mężczyzna nie ma ukończonych szesnastu lat, a kobieta czternastu lat życia. Prawo naturalne natomiast wymaga do zawarcia małżeństwa takiego wieku, który pozwalałby na zrozumienie tego, czym właściwie jest małżeństwo ${ }^{48}$. Kan. $1083 \S 2$ KPK z 1983 r. upoważnia Konferencję Biskupów do ustanowienia wyższego wieku do godziwego zawarcia małżeństwa, co jest to podyktowane ogromną troską, aby młodzi ludzie nie zawierali małżeństwa lekkomyślnie i bez uprzedniej dojrzałości umysłowej oraz przygotowania do samodzielnego życia ${ }^{49}$. Z kolei kan. 1072 KPK z 1983 r. poleca, aby duszpasterze starali się odwieść od małżeństwa młodocianych, którzy nie osiagnęli wieku, jaki zgodnie z miejscowym zwyczajem jest wymagany do zawarcia małżeństwa. Ponadto Konferencja Biskupów ustanawiając wiek do go-

${ }^{48}$ Zob. B. W. Zubert, Przeszkoda wieku do zaręczyn i matżeństwa $w$ prawie rzymskim, Roczniki Teologiczno - Kanoniczne 13 (1966), z. 5, s. 87- 98. Autor wyjaśnia, że według prawa rzymskiego koniecznym wymogiem zawarcia małżeństwa była dojrzałość fizyczna stron. Tak więc niewiasty dojrzałość tę osiągały po ukończeniu 12 roku życia, mężczyźni zaś po ukończeniu 14 lat; B. W. ZuBER, Małżeńska przeszkoda wieku w Dekrecie Gracjana i u pierwszych dekretystów, Roczniki Teologiczno - Kanoniczne 16 (1969), z. 5, s. 71-102. Autor zaznacza, że pod wpływem prawa rzymskiego kanoniści domagali się od narzeczonych, chcących zawrzeć związek małżeński dojrzałości fizycznej, a więc 12 i 14 lat życia, zgodnie z zasadą: matrimonium contrahi non potest, nisi inter puberes. W taki sposób rozumiana przeszkoda braku wieku posiadała charakter względny, z uwagi na to, iż małżeństwo uchodziło za ważne nawet przed ukończeniem 12 i 14 roku życia, gdy w konkretnym przypadku strony były dojrzałe pod względem fizycznym oraz były zdolne do spełnienia małżeństwa, a także posiadały dojrzałość umysłową, która pozwalała im na zrozumienie, czym właściwie jest małżeństwo. Ponadto sam fakt dojrzałości wcześniejszej miał pierwszeństwo przed domniemaniem prawnym. Warto zatem przypomnieć zapis Kodeksu Prawa Kanonicznego z 1917 r., gdzie w kan. 1062 § 2 zaznaczono, żeby nupturienci nie zawierali małżeństwa przed osiagnięciem wieku określonego zwyczajem miejscowym. Kodeks ten podniósł granicę wieku, bowiem zażądał od kobiety ukończonych 14 lat, a od mężczyzny 16 lat życia.

${ }^{49}$ T. Pawluk, Prawo kanoniczne wedtug Kodeksu Jana Pawła II. Prawo matżeńskie, t. 3, Olsztyn 1984, s. 126. 
dziwego zawarcia małżeństwa kierowała się zwyczajem miejscowym, czyli przepisami ustawy państwowej.

Warto przypomnieć, że od 15 listopada 1998 r. zgodnie z polskim prawem świeckim małżeństwo może zawierać mężczyzna, który ukończył 18 lat, ale bez możliwości uzyskania zezwolenia sądu rodzinnego na wcześniejsze zawarcie małżeństwa. Z kolei kobieta może zawierać małżeństwo w wieku 18 lat, z możliwością uzyskania zezwolenia sądu rodzinnego na wcześniejsze zawarcie małżeństwa po ukończeniu 16. roku życia ${ }^{50}$. Wiek ten określony przez polskie prawo rodzinne i opiekuńcze jest wymagany przy kanonicznym zawieraniu małżeństwa. Z Instrukcji Episkopatu Polski z dnia 13 grudnia 1989 r. o przygotowaniu do zawarcia małżeństwa w Kościele katolickim wynika, że: „Korzystając z uprawnień wynikających z kan. 1083 § 2 KPK z 1983 r. ustala do godziwości małżeństwa granicę wieku określoną aktualnie obowiązującym ustawodawstwem państwowym. (...) W wypadku gdy narzeczeni otrzymali od sądu opiekuńczego zezwolenie na wcześniejsze zawarcie małżeństwa, muszą też uzyskać dyspensę od ordynariusza miejsca. Jeżeli narzeczeni nie ukończyli jeszcze 18. roku życia (pełnoletność), trzeba zapytać, czy rodzice względnie opiekunowie wiedzą o zamiarze zawarcia małżeństwa i czy się na to zgadzają. W razie negatywnej odpowiedzi narzeczeni winni wyjaśnić, dla jakich powodów zamierzają zawrzeć ślub wbrew woli lub bez wiedzy rodziców. Po rozmowie z rodzicami, o ile to jest możliwe, duszpasterz przedstawia stan sprawy ordynariuszowi miejsca. Jeżeli racje rodziców są uzasadnione lub istnieją inne przeciwwskazania, ordynariusz miejsca ma prawo czasowego zakazania młodym związku małżeńskiego"

Zatem zastanawiając się nad problematyką dotyczącą osobowości niedojrzałej w odniesieniu do podjęcia istotnych obowiązków małżeń-

${ }^{50}$ Dz. U. 1998 nr 117, poz. 59.

${ }^{51}$ Instrukcja Episkopatu Polski o przygotowaniu do zawarcia matżeństwa w Kościele katolickim z dnia 13 grudnia 1989 r., w: Dokumenty duszpastersko - liturgiczne Episkopatu Polski 1966 - 1993, (oprac.) L. Adamowicz, Lublin 1994, s. 177-178. Sprawy związane z obniżeniem wieku dla mężczyzn zostały potwierdzone w Instrukcji dla duszpasterzy dotyczqcej matżeństwa konkordatowego z dnia 12 października 1998 r. w 1 części ogólnej, nr 8. 
skich zauważa się, że osoba z taką osobowością nie jest w stanie realizować większości istotnych obowiązków małżeńskich, czego przykładem może być wyrok Sadu Metropolitalnego Warszawskiego z dnia 5 października 2008 r., w którym zaznaczono, iż osoby szczególnie niepełnoletnie w okresie kojarzenia się małżeństwa ujawniają cechy osobowości zaburzonej lub jeszcze niedojrzałej ${ }^{52}$. Kolegium Sędziowskie wyjaśniło, że niedojrzałość ta odnosi się do jednego aspektu zachowania, czyli pochodzącego z pochopnego podjęcia decyzji o zawarciu małżeństwa wobec ciąży. W konkluzji wyroku zaznaczono, że silny nacisk społeczny do natychmiastowego zawarcia małżeństwa w przypadku ciąży przedślubnej doprowadził do tego, że w takich okolicznościach trudno było w sposób wolny i przemyślany podjąć właściwą decyzję. Poza tym podkreślono, iż istnieje trudność w różnicowaniu pewnych form niedojrzałości wynikłych z racji młodego wieku, od tych, które mają charakter patologiczny. Sędziowie kościelni wyjaśnili również, że nie jest to łatwy problem, z uwagi na to, że dojrzałość w danym wieku może być nawet bardzo różna w różnych sferach osobowościowych.

$\mathrm{Z}$ analizy większości procesów rozpatrywanych w sądach kościelnych, w których orzekano niezdolność osoby do podjęcia istotnych obowiązków małżeńskich, a osoba ta była niepełnoletnia, uwydatnia się osobowość niedojrzała, z którą wiąże się brak zdolności dokonania właściwego wyboru. Taka sytuacja miała miejsce w wyroku Sqdu Metropolitalnego Warszawskiego z dnia 29 września 2009 r., w którym podkreślono, że w przypadku osobowości niedojrzałej ma miejsce subiektywizacja systemu wartości i psychiczna niewrażliwość na war-

${ }^{52}$ ASMW nr akt 24992. W analizowanej sprawie kobieta w wieku 16 lat na skutek zaistniałej ciąży zawarła związek małżeński. Z kolei jeszcze przed poznaniem męża prowadziła współżycie seksualne. Przed zawarciem małżeństwa sakramentalnego zamieszkała z przyszłym mężem. Do Pierwszej Komunii św. przystąpiła dopiero przed samym ślubem. W trakcie małżeństwa dopuszczała się zdrad. Dochodziło do tego, że pozostawiała dziecko w domu z mężem i wychodziła z domu nie mówiąc, dokąd idzie i kiedy wróci. Świadkowie określają pozwaną, jako „wyprawiającą dziecinadę”. Z kolei powołany biegły sądowy - psycholog orzekł, że pozwana posiada niedojrzałość uwarunkowaną rozwojowo. 
tości wyższe - moralne, egocentryzm w relacjach interpersonalnych, a także labilność emocjonalna, czy też niestałość zachowań i wysoki niepokój oraz stosowanie niedojrzałych mechanizmów obronnych ${ }^{53}$. W konkluzji wyroku Kolegium Sędziowskie wyjaśniło, że niedojrzałość osobowościowa stron procesowych uczyniła $\mathrm{z}$ nich w aspekcie psychologicznym osoby niepełnosprawne, jak również ograniczyła obiektywizm poznania oraz zakłóciła właściwe funkcjonowanie ich systemu motywacyjnego, szczególnie w układach interpersonalnych.

Znawcy tematu wskazuja, że w związku z osobowością niedojrzałą podkreśla się defectus libertatis internae, co ma miejsce przy dość wczesnym wyborze partnera i ,zapoczątkowania małżeństwa" ${ }^{54}$. Wynika z tego, iż przejawem niedojrzałości związanej z młodym wiekiem może być pochopne podjęcie decyzji o zawarciu małżeństwa, jak również krótka i powierzchowna znajomość partnera, która w opinii młodych osób jest wystarczająca. Ponadto osoby te nie posiadają wystarczającej wiedzy na temat istoty małżeństwa oraz związanych z nim wzajemnych praw i obowiązków. Nie posiadają również podstawowych doświadczeń życiowych, dotyczących prowadzenia gospodarstwa domowego. Dlatego też należy zwrócić uwagę na to, że w procesach orzekających niezdolność osoby do podjęcia istotnych obowiązków małżeńskich z przyczyn natury psychicznej dość często sądy kościelne mają do czynienia z osobami niepełnoletnimi. Wobec tego biorąc pod uwagę analizowane wyroki nasuwa się wniosek, że przy ocenie zachowania się osób niepełnoletnich w zawartym małżeństwie należy rozróżnić osobowość

${ }^{53}$ ASMW nr akt 24283. W analizowanej sprawie mężczyzna, który w chwili ślubu miał 19 lat, jeszcze przed zawarciem małżeństwa za wyczyny chuligańskie był karany sądownie. Pozwany już jako mąż życie rodzinne traktował jak przygodę. Poza tym nadużywał alkoholu i pod jego wpływem stawał się agresywny i groźny. Ponadto pozwany dostawał „,białej gorączki” i przy tym urządzał straszne awantury. Poza tym bił żonę i krzyczał na dziecko, kiedy było chore. Powołany biegły sądowy - psycholog stwierdził, że pozwany jest osobą niedojrzałą i niezdolną do nawiązania głębokich związków emocjonalnych. Jednocześnie wskazał, że pozwany prezentuje płytki i powierzchowny stosunek do różnych problemów życiowych, w tym również do istoty małżeństwa.

${ }^{54}$ P. Weseman, Psychiczna niezdolność do matzeństwa jako problem sqdownictwa kościelnego, Kościół i Państwo, t. 3, Lublin 1984, s. 90-91. 
niedojrzałą od osobowości już zaburzonej, jaką przejawiali wchodząc w sakramentalny związek małżeński. W związku z tym można powiedzieć, że w większości przeanalizowanych spraw spotyka się osobowość niedojrzałą. Dlatego też, zgodnie z tym, co twierdzą niektórzy autorzy, odróżnienie jednej osobowości od drugiej nastręcza czasami problem, którym powinien się zając powołany biegły sądowy, czy to psycholog, czy też psychiatra ${ }^{55}$. Poza tym warto zauważyć, że problematyka dotycząca osobowości niedojrzałej była przedmiotem dyskusji także w wyrokach Roty Rzymskiej ${ }^{56}$.

\section{Zakończenie}

W procesach kościelnych problematyka dotycząca kwestii osobowości niedojrzałej pojawia się zarówno w orzecznictwie Roty Rzymskiej, jak i w wyrokach trybunałów kościelnych, jako przyczyna niezdolności osoby do podjęcia istotnych obowiązków małżeńskich. W niektórych zaś procesach, gdy chodzi o osobę niepełnoletnią, występuje także tytuł poważnego braku rozeznania oceniającego. Niemniej jednak problem związany z osobowością niedojrzałą jest poważny wówczas, gdy chodzi o jej wykazanie i udowodnienie. $\mathrm{Z}$ analizy akt procesowych wynika, że niejednokrotnie pojawiają się trudne do

${ }^{55}$ S. Steuden, Zadania psychologa $w$ sprawach o stwierdzenie nieważności matżeństwa, (red.) Z. Płużek, Psychologia pastoralna, Kraków 1994, s. 202-227.

56 Por. dec. z dnia 13 maja 1972 r. c. Ewers, Monitor Ecclesiasticus 98 (1973), s. 199-200; dec. z dnia 6 lutego 1979 r. c. Ferraro, SRRD 71 (1979), s. 127-128; dec. z dnia 15 marca 1983 r. c. Calagiovanni, Monitor Ecclesiasticus 110 (1985), s. 328-338; dec. z dnia 12 stycznia 1984 r. c. Parisella, Monitor Ecclesiasticus 111 (1986), s. 290296; dec. z dnia 19 października 1985 r. c. Di Felice, Monitor Ecclesiasticus 111 (1986), s. 156-161; dec. z dnia 30 marca 1986 r. c. Pinto, Monitor Ecclesiasticus 111 (1986), s. 384-395; dec. z dnia 1 lipca 1988 r. c. Doran, Monitor Ecclesiasticus 114 (1989), s. 329-346; dec. z dnia 27 stycznia 1989 r. c. Civili, RRD 81 (1989), s. 77-82; dec. z dnia 20 grudnia 1990 r. c. Davino, Monitor Ecclesiasticus 116 (1991), s. 535-543; dec. z dnia 18 grudnia c. Palestro, Monitor Ecclesiasticus 117 (1992), s. 186-200; dec. z dnia 10 lipca 1992 r. c. Davino, Monitor Ecclesiasticus 118 (1993), s. 331-346; dec. z dnia 2 grudnia 1993 r. c. Burke, Monitor Ecclesiasticus 123 (1998), s. 507-525; dec. z dnia 27 października 1994 r. c. Burke, Monitor Ecclesiasticus 121 (1996), s. 494-512; dec. z dnia 31 maja 1995 r. c. Faltin, Monitor Ecclesiasticus 120 (1995), s. 508-525; dec. z dnia 31 stycznia 1997 r. c. Bruno, Monitor Ecclesiasticus 123 (1998), s. 196-246. 
rozwiązania problemy dotyczące różnicowania osobowości niedojrzałej albo jeszcze niedojrzałej od nieprawidłowo ukształtowanej czy też zaburzonej. W odniesieniu do tytułu nieważności $\mathrm{z}$ racji niezdolności do podjęcia istotnych obowiązków małżeńskich z przyczyn natury psychicznej z pewnością ważna jest kwestia niedojrzałości emocjonalnej i społecznej. Przejawia się ona na co dzień w braku uświadomienia podjętych zobowiązań i obowiązków oraz braku przygotowania do ich wypełnienia. Poza tym uwidacznia się w sposobie traktowania małżeństwa i rodziny oraz brakiem w sposobie przygotowania do współżycia i współdziałania w układach mąż - żona.

Reasumując należy podkreślić, iż z uzasadnień orzeczeń rotalnych i wyroków trybunałów kościelnych wynika, że kwestia dotycząca osobowości niedojrzałej stanowi przyczynę nieważności małżeństwa. Tak więc z analizy wydanych wyroków w okresie ostatnich kilkunastu lat wynika, że istnieje już dość dobrze ugruntowana tendencja, która kwalifikuje osobowość niedojrzała, zgodnie z kan. 1095 nn. 2-3 KPK z 1983 r. w ramach tytułu poważnego braku rozeznania oceniającego albo niezdolności do podjęcia istotnych obowiązków małżeńskich. Ponadto brak dojrzałości emocjonalnej w wielu przypadkach spowodował niezdolność osoby do tworzenia relacji interpersonalnych, a tym samym do zawiązania trwałego przymierza małżeńskiego.

\section{Immature personality as basis for annulment in the light of Roman Rota judgments and ecclesiastical tribunals decisions}

In many decisions of the Roman Rota and judgments of ecclesiastical tribunals, marriage was annulled because of the presence of immature personality in the litigants that makes people unable to take the essential obligations of marriage. From the analysis of court records of the annulment of marriage result that in regards to marriage we can not speak of full maturity or the full maturity of marriage. We can speak only of a suitable maturity meaning the minimum and therefore the canonical maturity which is required by law for a valid marriage. The study of the canonical processes for annulment of marriage shows that a person with an immature personality is not able to fulfill the obligations arising from the contract of marriage. In addition, processes analysis showed that the negative symptoms of an immature personality in the marriage usually existed from the very beginning and that is why the couple were not able to establish deeper emotional connections. 